Original Research Article

\title{
Preliminary study on antiulcer effect of agomelatine and its potentiation with pyridoxine
}

\author{
Pooja Shukla ${ }^{1}$, Anisha Porwal ${ }^{1 *}$, Suman Roy ${ }^{2}$, Shivam Chaturvedi ${ }^{3}$, \\ Smriti Tripathi ${ }^{4}$, Nalini Arya ${ }^{1}$
}

${ }^{1}$ Department of Pharmacology, Era's Lucknow Medical College and Hospital, Lucknow, Uttar Pradesh, India

${ }^{2}$ GSS Lab, Brahma Lab Facility, Genus Breeding India Pvt. Ltd., Brahmanandnagar, Sangli, Pune, Maharashtra, India

${ }^{3}$ Department of Animal House, International Centre for Genetic Engineering and Biotechnology, New Delhi, India

${ }^{4}$ Department of Pharmacology, Advance Institute of Biotech and Paramedical Sciences, Kanpur, India

Received: 10 August 2017

Revised: 28 August 2017

Accepted: 01 September 2017

*Correspondence to:

Dr. Anisha Porwal,

Email: anisha.porwal.1991@ gmail.com

Copyright: (C) the author(s), publisher and licensee Medip Academy. This is an openaccess article distributed under the terms of the Creative Commons Attribution NonCommercial License, which permits unrestricted noncommercial use, distribution, and reproduction in any medium, provided the original work is properly cited.

\begin{abstract}
Background: Agomelatine is a synthetic analogue of melatonin and a potent agonist of melatonin receptors. Agomelatine has Hepatoprotective as well as antioxidant activity. The aim of study was to evaluate the antiulcer activity of Agomelatine and its potentiation through the pyridoxine on ethanol induced gastric ulcer in rats.

Methods: Thirty number of rats were divided in to five groups contro, standard, Agomelatine low dose, Agomelatine high dose and Agomelatine with Pyridoxine groups. Ethanol was used to induced gastric ulcer in rats. ulcer index and also the other biochemical parameters like free Acidity, total Acidity, gastric $\mathrm{pH}$, volume of gastric juice was determined. Statistically analysis was done by ANOVA P value less than 0.05 was considered Statistically significant.

Results: In the present study, an attempt has been made to investigate the gastric antisecretory, antiulcer and cytoprotective properties of agomelatine. The results are statistically significant by ANOVA test. Ranitidine showed a statistically significant decrease in the volume of gastric juice by free acidity and total acidity. when compared to control. Agomelatine shows a showed similar response to the volume of gastric juice. A significant difference in $\mathrm{pH}$ was observed between the agomelatine-treated, agomelatine with pyridoxine treated group and the control groups.

Conclusions: Pretreated rats with Agomelatine $(40 \mathrm{mg} / \mathrm{kg}$ ) showed protective effect against ethanol induce gastric ulcer. Agomelatine $(40 \mathrm{mg} / \mathrm{kg}$ ) showed the ameliorative effect with Pyridoxine $(0.3 \mathrm{mg} / \mathrm{kg})$, on gastric ulcer.
\end{abstract}

Keywords: Agomelatine, Ethanol, Gastric ulcer, Pyridoxine, Ranitidine

\section{INTRODUCTION}

Ethanol (EtOH) consumption is considered to be a risk factor in the development of gastroduodenal ulcers. Intragastrically administered EtOH rapidly penetrates the 
gastrointestinal mucosa, causing membrane damage, exfoliation of cells and erosion. ${ }^{1,2}$ Generation of free radicals has also been suggested as one of the mechanisms responsible for EtOH-induced gastroduodenal injury. 3,4 Most peptic ulcers developed as a result of chronic alcoholism. $^{4}$

Agomelatine is an innovative antidepressant recently licensed by the European Medicines Agency for the treatment of major depressive episodes in adults. The combined actions of agomelatine at $\mathrm{MT}_{1}, \mathrm{MT}_{2}$, and $5 \mathrm{HT}$ $2 \mathrm{C}$ receptors can improve the disturbed circadian rhythm and abnormal sleep pattern thus produce the antidepressant effect. ${ }^{5,6}$ The administration of Agomelatine $(40 \mathrm{mg} / \mathrm{kg}$ ) protects liver cells from paracetamol-induced hepatotoxicity via antioxidant activity and reduced proinflammatory cytokines, such as TNF- $\alpha$ and IL-6. ${ }^{7}$

\section{Basis of research}

The metabolism of EtOH is the main cause the production of reactive oxygen species and ultimately oxidative stress which play pro ulcerogenic effects for gastric injury. ${ }^{8}$ In the present research work we used antioxidant property of agomelatine as scavengers of oxygen species and potentiation through pyridoxine, in curing and treating ulcer. On the basis of earlier study which tells the receptor is present in stomach, so on the basis of this Agomelatine have some Antiulcer action.

\section{METHODS}

Agomelatine was obtained from Precise Chemi pharma pvt. Ltd (Navi Mumbai), Ranitidine hydrochloride and pyridoxine were purchased from Sigma Chemical Co, were all suspended in $0.5 \%$ Xanthan Gum suspension. Wistar Albino rats of either weight between 180-210gm were used for the study. The animals were house in standard condition temperature $\left(23^{\circ} \mathrm{C} \pm 2\right)$, humidity $(55 \pm 5 \%)$ and $12 \mathrm{~h}$ light and $12 \mathrm{~h}$ dark cycles. The animals were fed with standard pellet diet and water ad libitum. The study was in accordance with the guideline of the Committee for the Purpose of Control and Supervision of Experimental Animal (CPCSEA). Throughout the study period, all animals were observed for behavioural signs of toxicity, morbidity and mortality.

The animal was divided in to five groups (each contain 6 animals) as follow:

- Group - I(Control): Vehicle x 6

- Group - II (Standard): Ranitidine (200mg/kg) x 6

- Group - III: Agomelatine $(30 \mathrm{mg} / \mathrm{kg}) \times 6$

- Group - IV: Agomelatine (40mg/kg) x 6

- Group - V: Agomelatine and pyridoxine $(0.3 \mathrm{mg} / \mathrm{kg}) \times 6$

On day 5, the animals of II, III, IV and V were orally administered with ranitidine $(200 \mathrm{mg} / \mathrm{kg})$, Agomelatine $(30 \mathrm{mg} / \mathrm{kg})$, Agomelatine $(40 \mathrm{mg} / \mathrm{kg})$, Agomelatine and
Pyridoxine $(0.3 \mathrm{mg} / \mathrm{kg})$ respectively, $1 \mathrm{hr}$. prior to administration of $1 \mathrm{ml}$ absolute ethanol.

One hour after administration of ethanol, the animals were euthanized with $\mathrm{CO}_{2}$, the stomachs were isolated and cut along the greater curvature, ulcer score was done. Gastric juice was collected and gastric secretions studied were performed. The number and severity of ulcers is registered with a stereo-microscope using the following scores:

\section{Scoring of ulcer ${ }^{9}$}

- $0=$ Normal coloured stomach

- $0.5=$ Red colouration

- 1 = Spot ulcer

- $1.5=$ Haemorrhagic streaks

- $2=$ Ulcers $\geq 3$ but $\leq 5$

- $3=$ Ulcers $>5$

\section{Calculation of ulcer index ${ }^{9}$}

- $\mathrm{UI}=\mathrm{UN}+\mathrm{US}+\mathrm{UP} \times 10-1$

- $\mathrm{UI}=$ Ulcer Index.

- $\mathrm{UN}=$ Average of number of ulcers per animal.

- $\mathrm{US}=$ average of severity score.

- $\mathrm{UP}=$ percentage of animals with ulcers.

\section{Assessment of gastric mucosal lesions ${ }^{10}$}

The gastric mucosal lesions were expressed in terms of ulcer index (U.I.), which depends on the calculation of a lesion index by using a scoring system based on the severity of each lesion. The severity factor was defined according to the length of the lesions. Severity factor $0=$ no lesions; $1=$ lesions < $1 \mathrm{~mm}$ length; $2=$ lesions $2-4 \mathrm{~mm}$ length and $3=$ lesions $>4 \mathrm{~mm}$ length.

\section{Analysis of gastric juice $e^{10}$}

Gastric juice collected from each animal and centrifuged at $3000 \mathrm{rpm}$ for $10 \mathrm{~min}$ to remove any solid debris and the volume of the supernatant was measured. The supernatant was then assayed for the $\mathrm{pH}$, Free and total acidity.

\section{Determination of free and total acidity ${ }^{11}$}

Acidity was calculated using the following formula:

Acidity $=\underline{\text { Volume of } \mathrm{NaOH} \times \text { Normality of } \mathrm{NaOH} \times 100}(\mathrm{Meq} / \mathrm{lit} / 100 \mathrm{gm})$ 0.1

\section{Histopathological study}

The stomach from all groups were removed rapidly, and prepared the slides which were observed under binocular microscope at different magnifications. 


\section{Statistical analysis}

Statistical analysis in all the above studies was performed using Graph Pad Prism software. All result was expressed as mean \pm S.E.M. Data were analyzed using one-way analysis of variance (ANOVA), and followed by Dennet's multiple comparison tests. Value $\mathrm{P}<0.05$ and below were considered significant.

\section{RESULTS}

In the present study, an attempt has been made to investigate the gastric antisecretory, antiulcer and cytoprotective properties of agomelatine. Intragastric administration of one $\mathrm{ml}$ ethanol consistently caused hemorrhagic lesions in the mucosa of the glandular stomach.

The control group showed ulceration, redness and hemorrhagic streaks, after ethanol administration. It is evident from (Table 1) and (Table 2) that the ulcer index of agomelatine is comparable with ranitidine against the control. The results are statistically significant by ANOVA test. Ranitidine showed a decrease in the volume of gastric juice by free acidity and total acidity.

Table 1: Estimation of pH, free acidity and total acidity of gastric juice.

\begin{tabular}{|lllll|}
\hline \multicolumn{1}{|c|}{$(\mathbf{M e q} / \mathrm{lit} / \mathbf{1 0 0 g m})$} & $\mathrm{pH}$ & Volume of gastric juice $(\mathrm{ml})$ & Free acidity & Total acidity \\
\hline Control group & $1.3 \pm 0.0$ & $2.7 \pm 0.4$ & $21.96 \pm 0.9$ & $81.1 \pm 0.63$ \\
\hline LD group $(30 \mathrm{mg} / \mathrm{Kg})$ & $2.0 \pm 0.33^{\mathrm{a}}$ & $2.0 \pm 0.8^{\mathrm{a}}$ & $19.1 \pm 0.5^{\mathrm{a}, \mathrm{b}, \mathrm{c}}$ & $57.1 \pm 0.88^{\mathrm{a}}$ \\
\hline HD group $(40 \mathrm{mg} / \mathrm{Kg})$ & $2.66 \pm 0.33^{\mathrm{a}, \mathrm{b}, \mathrm{c}}$ & $1.9 \pm 0.05^{\mathrm{a}, \mathrm{b}, \mathrm{c}}$ & $13.2 \pm 0.5^{\mathrm{a}, \mathrm{b}, \mathrm{c}}$ & $53.4 \pm 0.78^{\mathrm{a}, \mathrm{b}, \mathrm{c}}$ \\
\hline Pyridoxine group $(0.3 \mathrm{mg} / \mathrm{Kg})$ & $3.33 \pm 0.33^{\mathrm{a}, \mathrm{b}, \mathrm{c}}$ & $1.6 \pm 0.8^{\mathrm{a}, \mathrm{b}, \mathrm{c}}$ & $12.0 \pm 0.43^{\mathrm{a}, \mathrm{b}, \mathrm{c}}$ & $47.6 \pm 0.78^{\mathrm{a}, \mathrm{b}, \mathrm{c}}$ \\
\hline Standard group $(200 \mathrm{mg} / \mathrm{Kg})$ & $4.0 \pm 0.33^{\mathrm{a}}$ & $0.86 \pm 0.1^{\mathrm{a}}$ & $9.7 \pm 0.29^{\mathrm{a}}$ & $\mathrm{ss} 37.4 \pm 0.61^{\mathrm{a}}$ \\
\hline
\end{tabular}

Values are expressed as mean \pm SEM, $n=6 ; \mathrm{P}$ value of $<0.05$ as compared with control using Dunnett's multiple comparison test

a - Significantly difference from control group P $<0.05 ;{ }^{b}$ - Significantly difference from LD group P $<0.05{ }^{\circ}{ }^{\mathrm{C}}$ - Significantly difference from standard group $\mathrm{P}<0.05$.

Table 2: Estimation of ulcer score and ulcer index.

\begin{tabular}{|lll|}
\hline Treatment & Ulcer score & Ulcer index \\
\hline Control group & $1.66 \pm 0.16$ & $5.7 \pm 0.24$ \\
\hline LD group $(30 \mathrm{mg} / \mathrm{Kg})$ & $1.2 \pm 0.16^{\mathrm{a}}$ & $3.8 \pm 0.17^{\mathrm{a}}$ \\
\hline HD group $(40 \mathrm{mg} / \mathrm{Kg})$ & $0.66 \pm 0.16^{\mathrm{a}, \mathrm{b}, \mathrm{c}}$ & $3.4 \pm 0.11^{\mathrm{a}, \mathrm{b}, \mathrm{c}}$ \\
\hline $\begin{array}{l}\text { Pyridoxine group } \\
(0.3 \mathrm{mg} / \mathrm{Kg})\end{array}$ & $0.83 \pm 0.16^{\mathrm{a}, \mathrm{b}, \mathrm{c}}$ & $2.4 \pm 0.24^{\mathrm{a}, \mathrm{b}, \mathrm{c}}$ \\
\hline $\begin{array}{l}\text { Standard group } \\
(200 \mathrm{mg} / \mathrm{Kg})\end{array}$ & $0.66 \pm 0.16^{\mathrm{a}}$ & $2.1 \pm 0.08^{\mathrm{a}}$ \\
\hline
\end{tabular}

Values are expressed as mean \pm SEM, $n=6$; $\mathrm{P}$ value of $<0.05$ as compared with control using Dunnett's multiple comparison test. a - Significantly difference from control group $\mathrm{P}<0.05 ;{ }^{\mathrm{b}}$ Significantly difference from LD group $\mathrm{P}<0.05$; $^{\mathrm{C}}$ - Significantly difference from standard group $\mathrm{P}<0.05$.

Agomelatine shows a decrease in the volume of gastric juice by free acidity and total acidity. which is also statistically significant. A significant difference in $\mathrm{pH}$ was observed between the agomelatine-treated and the control groups.

\section{DISCUSSION}

Agomelatine was found to significantly inhibit alcohol induced ulcers at all doses tested. The antiulcer capacity of Agomelatine was determined to be dose dependent; $40 \mathrm{mg} / \mathrm{kg}$ dose of Agomelatine inhibited alcohol-induced ulcer more significantly.
Alcohol consumption can produce acute hemorrhagic, gastric erosions, and excessive ingestion can result in gastritis characterised by mucosal edema, sub-epithelial hemorrhages, cellular exfoliation, and inflammatory cell infiltration. ${ }^{12,13}$ Absolute ethanol is highly corrosive to the gastric mucosa and its mechanism of action on rat gastric mucosa involves superficial necrosis of gastric mucosa and release of histamine and leukotriene $\mathrm{C}_{4}$ as tissuederived mediators. Ethanol-induced gastric ulcers have been widely used for the experimental evaluation of antiulcer activities; this method of inducing gastric lesions is a rapid and convenient way of screening cytoprotective drug as anti-ulcer potency. The present histopathological result of ethanol-induced gastric ulcer is similar to previous studies of ethanol-induced gastric mucosal injury. ${ }^{14}$

In many experimental studies, antidepressant drugs have been shown to produce antiulcer effects by reducing histamine secretion from mast cells, inhibiting gastric acid secretion, and blocking leukotriene $\left(\mathrm{LTC}_{4}, \mathrm{D}_{4}, \mathrm{E}_{4}\right)$ receptors. ${ }^{14,15}$ Melatonin completely protects ulcer. The mechanism for this is independent of any modulation of acid secretion, may act as a potent free radical scavenger, Increasing mucosal blood flow, Increasing the $\mathrm{PGI}_{2}$, Free radicals scavenger property, decreasing $\mathrm{TNF}^{16}{ }^{16}$ Agomelatine is a potent oral agonist at $\mathrm{MT}_{1}$ and $\mathrm{MT}_{2}$, so it is hypothesized that it is able to protect ulcer by following above ways. ${ }^{17}$ The current study, all doses of Agomelatine, which exerted a significant antiulcer effect, also increased 
gastric $\mathrm{pH}$ levels and decrease in gastric volume, Ulcer Index, free acidity and total acidity, significantly when compared to the control. MEL's antioxidant properties can also be additive to the treatment of gastric ulcer, bowel syndrome, ulcerative colitis. MEL may act as a potent free radical scavenger, by neutralizing hydroxyl and peroxyl radicals among others, preventing lipid membrane peroxidation, apoptosis, and protecting the DNA from the damage induced by free radicals. ${ }^{18,19}$

The presented study has demonstrated that pre-treatment with Agomelatine protected the gastric mucosa from ulcer induction by absolute ethanol, and the protection of the gastric mucosa was morphologically improved when the doses were increased. The repair of ulcer damage requires a complete reestablishment of the connective tissue of the mucosa, the underlying submucosa, the re-formation of glandular architecture, and the growth of new blood vessels.

The present study revealed that the ethanol-induced gastric ulcer can be healed by using agomelatine to restore an integrity of gastric wall in most of the cases within a short time as in compared to a non medicated; however, the healing results are as in impressive as those obtained by treating the subject with ranitidine. The current data clearly demonstrated that agomelatine inhibited the aggressive factor and gastric acid secretion. The antiulcerogenic effect of agomelatine may be related to its antisecretory action because acid is a major factor in the development of peptic ulcer. The protective effects against ethanol induce gastric ulcer were associated with reduce free acidity, total acidity, gastric volume and ulcer index, when compared with ranitidine.

\section{CONCLUSION}

This study is acute study or single dose study. In conclusion, the result of the present study suggests that Agomelatine $(40 \mathrm{mg} / \mathrm{kg}$ ) has Significant gastroprotective effects against ethanol induced gastric ulcer, and also the combination group (Agomelatine $40 \mathrm{mg} / \mathrm{kg}+$ Pyridoxine $0.03 \mathrm{mg} / \mathrm{kg}$ ) showed more Significant gastroprotective on gastric ulcer. Histopathological observation indicated that Agomelatine have enough potential to suppress ulcer at the dose of $40 \mathrm{mg} / \mathrm{kg}$, and more potential effect is obtained with Pyridoxine. agomelatine significantly protect gastric mucosal lesion against ethanol-induced damage. Such protection was shown to be dose dependent as certained by the reduction of ulcer areas in the gastric wall, reduction or inhibition of edema. However, further detailed studies are warranted for the wide use of Agomelatine as therapy for gastric ulcer.

Funding: No funding sources Conflict of interest: None declared

Ethical approval: The study was approved by the Institutional Ethics Committee

\section{REFERENCES}

1. Kim CD, Hong KW. Preventive effect of rebamipide on gastric lesions induced by ischemia-reperfusion in the rat. J Pharmacol Exp. 1995;275:340-90.

2. Al-Qaraghuli, Abdel WEMN, Al-Ani IM, Faisal GG. Effects of Xiang Sha Yang Wei Wan on EthanolInduced Gastric Ulcer in Sprague Dawley Rats: A Histological Study. The international Medical Journal Malaysia. 2013;12:3-8.

3. Pihan G, Regillo C, Szabo S. Free radicals and lipid peroxidation in ethanol- or aspirin-induced gastric mucosal injury. Dig Dis Sci. 1987;32:1395-401.

4. Manso CF. Alcohol and free radicals. Various consequences: protein synthesis, endocrine disorders, immunity, role of stress. Acta Med Port. 1997;10:80917.

5. Stein DJ, Kennedy SH. Efficacy of the novel antidepressant agomelatine for anxiety symptoms within depression. Affective disorders and antidepressants. 2008;383.

6. Girish MB, Bhuvana K, Nagesh RG, Sarala N. A novel atypical antidepressant drug: Agomelatine - A review. Int J Pharm Biomed Res. 2010;1(3):113-6.

7. Karakus E, Halici Z, Albayrak A, Polat B, Bayir Y, Kiki I. Agomelatine: An antidepressant with new potent hepatoprotective effects on paracetamolinduced liver damage in rats. Hum Exp Toxicol. 2013.

8. Sener G, Paskaloglu K. Protective of increasing dose of famotidine, omeprazole, lansoprazole and melatonine against ethanol induced gastric damage in rats. Indian journal of pharmacology. 2004;36(3):1714.

9. Vogel, Gerhard H. Drug Discovery and Evaluation. New York, Springer; 2002.

10. Abdulla MA, Bayaty FH, Younis LT, Hassan MI. Anti-ulcer activity of Centellaasiatica leaf extract against ethanol-induced gastric mucosal injury in rats. Journal of Medicinal Plants Research. 2010;4:1253-9.

11. Srivastava V, Viswanathaswamy AHM, Mohan G. Determination of the antiulcer properties of sodium cromoglycate in pylorus-ligated albino rats. Indian $\mathbf{J}$ Pharmacol. 2010;42:185-8.

12. Guslandi M. Effects of ethanol on the gastric mucosa. Digest Dis. Sci. 1987;5:21-32.

13. Ko JK, Cho CH, Lam SK. Adaptive cytoprotection through modulation of nitric oxide in ethanol-evoked gastritis. World J. Gastroenterol. 2004;17:2503-8.

14. Hano J, Bugajski J, Wantuch C. The effect of drugs interfering with biogenic amines metabolism on gastric secretion and reserpine-ulcers development in rats.JPharmacol Pharm. 1978;30:501-11.

15. Theoharides TC, Bondy PK, Tsakalos ND, Askenase PW. Differential release of serotonin and histamine from mast cells. Nature. 1982;297:229-31.

16. Chowdhury I, Mantra S. Melatonin Time Line: From Discovery to Therapy. Taylor \& Francis Group. 2012;2:24-30.

17. Tardito D, Molteni R, Popoli M, Racagni G. Synergistic mechanisms involved in the antidepressant 
effects of agomelatine. European Neuropsychopharmacology. 2012;22:482-6.

18. Bandyopadhyay D, Biswas $\mathrm{K}$, Bhattacharyya $\mathrm{M}$, Reiter RJ, Banerjee RK. Involvement of reactive oxygen species in gastric ulceration: Protection by melatonin. Indian J Exps Biol. 2002;40:693-705.
19. Ferraz FF, Kos AG, Janino P, Homsi E. Effects of melatonin administration to rats with glycerol induced acute renal failure. Renal Fail. 2002;24:735-46.

Cite this article as: Shukla P, Porwal A, Roy S, Chaturvedi S, Tripathi S, Arya N. Preliminary study on antiulcer effect of agomelatine and its potentiation with pyridoxine. Int $\mathrm{J}$ Basic Clin Pharmacol 2017;6:2566-70. 